\title{
Minuman Probiotik dari Limbah Kulit Nanas sebagai Upaya Peningkatan Imunitas dalam Pencegahan Covid-19 di Kelompok PKK RT.06/RW.03 Rungkut Barata Surabaya
}

\author{
Riski Ayu Anggreini ${ }^{1}$, Noni Rahmadhini ${ }^{2}$, Laksmi Diana ${ }^{3}$ \\ ${ }^{1}$ Program Studi Teknologi Pangan, Fakultas Teknik \\ ${ }^{2}$ Program Studi Agroteknologi, Fakultas Pertanian \\ ${ }^{3}$ Program Studi Agribisnis, Fakultas Pertanian \\ Universitas Pembangunan Nasional "Veteran" Jawa Timur \\ Jalan Raya Rungkut Madya, Gunung Anyar Surabaya
}

Email : riskiayua.tp@upnjatim.ac.id

\begin{abstract}
Abstrak - Penyakit Covid-19 telah ditetapkan sebagai pandemi dan telah tersebar di 216 negara di seluruh dunia. Data sebaran yang didapatkan dari WHO (2020) pada tanggal 31 Mei 2020 menyebutkan bahwa kasus positif Covid-19 di dunia adalah 5.891.182 jiwa dengan kasus kematian sebesar 365.966 jiwa. Kondisi di Indonesia juga cukup serius, yaitu kasus positif sebesar 25.773 jiwa dengan kasus meninggal 1573 jiwa. Covid-19 berpotensi menyerang manusia yang memiliki imunitas yang tidak baik, sehingga kemudian gaya hidup sehat memiliki peranan dalam meningkatkan sistem imun, diantaranya dengan konsumsi pangan sehat seperti probiotik. Salah satu media yang dapat digunakan untuk menumbuhkan probiotik adalah kulit nanas. Mitra kegiatan pengabdian masyarakat adalah warga PKKRT.6/RW.3 Rungkut Barata, yang mayoritas berada pada usia middle aged dan lansia. Usia ini dianggap rentan terpapar Covid-19, sehingga pada kegiatan ini kami berencana untuk melakukan kegiatan pengabdian masyarakat terkait probiotik menggunakan limbah kulit nanas. Lokasi mitra sendiri dianggap strategis karena terletak di dekat pasar dan dikelilingi oleh beberapa penjual buah nanas. Adapun metode kegiatan yang kami lakukan adalah dimulai dari persiapan dan koordinasi dengan calon mitra, kemudian dilanjutkan dengan penyuluhan dan pelatihan pembuatan produk probiotik dari kulit nanas. Luaran berupa produk probiotik, modul pelatihan dan dokumentasi baik cetak maupun elektronik.
\end{abstract}

Kata kunci: probiotik, limbah kulit nanas, tepache

\begin{abstract}
Covid-19 has been declared as pandemic and has spread in 216 countries around the world. WHO's distribution data obtained on May 31, 2020 that there were 5,891,182 positive cases of Covid-19 in the world with 365,966 deaths. The condition in Indonesia is classified as serious as well, which 25,773 positive cases with 1,573 deaths. Covid-19 has the potential to attack humans with poor immunity, so that a healthy lifestyle plays a role in increasing endurance, such as eating healthy food like probiotics. One of the media that can be used to grow probiotics is pinneapple peel. The community service partner was PKK RT. 06/RW.03 Rungkut Barata residents, the majority of whom are middle aged and elderly. This age is classified as vulnerable to being exposed to Covid-19, so in this acrivity we plan to carry out activity related to probiotics by utillizing pineapple skin waste. Futhermore, the location of the partners is strategic because near the market and sorrounded by several pineapple sellers. The method activity was preparation and coordination with the partner, then continues with conselling and training on making probiotic product. The output was probiotic product, training moduls and documentation.
\end{abstract}

Keywords : probiotics, pineapple skin waste, tepache 


\section{LATAR BELAKANG}

Penderita Covid-19 semakin mengalami peningkatan dari hari ke hari. Covid-19 merupakan penyakit menular yang disebabkan oleh virus corona. Penyakit ini awalnya ditemukan di Wuhan China, yang kemudian berkembang menjadi pandemi dan terjadi hampir di seluruh dunia. kasus positif Covid-19 di dunia adalah 5.891.182 jiwa [1]. Sementara itu, data terbaru dari menyebutkan bahwa jumlah kasus positif Covid-19 di Indonesia semakin mengalami peningkatan menjadi 25.773 jiwa, dengan kasus meninggal terbanyak terjadi pada rentang usia 45-59 tahun dan usia di atas 60 tahun [2]. Surabaya merupakan salah satu kota penyumbang pasien positif Covid-19 terbesar di Indonesia. Data terbaru menunjukkan bahwa pasien positif yang berasal dari Surabaya adalah mencapai 2495 jiwa [3]. Upaya untuk mencegah Covid-19 diantaranya adalah dengan gaya hidup bersih dan menjaga kesehatan/imunitas. Imunitas dapat ditingkatkan diantaranya dengan diet makanan sehat seperti probiotik.

Probiotik merupakan bakteri baik yang jika dikonsumsi dapat lolos sampai kolon, yang kemudian dapat memberikan sumbangsih terhadap kesehatan dan meningkatkan kekebalan tubuh. Probiotik dapat ditumbuhkembangkan pada bahan pangan tertentu seperti pada komoditas nanas. Nanas merupakan salah satu komoditas buah yang ketersediaan dan permintaannya cukup tinggi. Buah nanas dapat dikonsumsi langsung ataupun dapat digunakan sebagai bahan isian produk minuman. Pemanfaatan buah nanas yang cukup tinggi ini ternyata menimbulkan masalah lain yaitu dihasilkannya limbah kulit nanas yang cukup banyak. Limbah kulit nanas memiliki kandungan karbohidrat yang cukup tinggi sehingga potensial digunakan sebagai media pertumbuhan probiotik. Kandungan karbohidrat di dalam kulit nanas dalam $100 \mathrm{~g}$ bahan adalah $17,53 \mathrm{~g}$ [4].

Probiotik dapat memberikan dampak yang positif terhadap kesehatan. Probiotik dianggap mampu menghasilkan senyawa anti mikroba, mampu berkompetisi dengan patogen dalam pada saat penempelan di saluran cerna sehingga mampu mencegah terjadinya infeksi saluran cerna dan juga mampu meningkatkan penyerapan zat gizi, meningkatkan mucosal barrier integrity dan modulasi imun [5][6]. Hal ini linear dengan pernyataan [7] yang menyebutkan bahwa probiotik dapat berperan terhadap peningkatan bakteri baik kolon (gut microbiota), kesehatan sistem pencernaan dan sistem imun. Harapannya dengan adanya kegiatan pengabdian masyarakat ini, dapat mengedukasi masyarakat mengenai upaya lain yang dapat dilakukan sebagai salah satu pencegahan Covid-19, yaitu dengan memanfaatkan potensi sekitar yang ada.

\section{ANALISA SITUASI}

Rungkut barata merupakan kawasan yang terletak di kawasan rungkut Surabaya, sehingga sangat berpotensi terpapar Covid-19, terlebih setelah kasus Sampoerna di awal bulan Mei 2020 lalu. Rungkut barata umumnya dihuni oleh usia produktif/pekerja dan pensiunan. Calon mitra kegiatan pengabdian ini adalah middle aged dan lansia (pensiunan), dengan rentang usia $\pm 50-60$ tahun. Covid-19 berpotensi menyerang semua usia, hanya saja middle aged dan atau lansia memiliki potensi lebih besar untuk terserang. Dilihat dari kemudahan akses untuk mendapatkan bahan baku, kawasan rungkut barata dianggap masih strategis, karena berada di dekat pasar Soponyono dan toserba Yakaya.

Permasalahan yang dimiliki oleh kelompok PKKRT.6/RW.3 Rungkut Barata. Kelurahan Rungkut Barata, Kecamatan Gunung Anyar Surabaya adalah belum memanfaatkan limbah kulit nanas dengan optimal dan kurangnya informasi terkait probiotik, peranan serta aplikasinya pada produk pangan.

\section{SOLUSI DAN LUARAN}

Dari beberapa paparan terkait permasalahan mitra yang telah dikemukakan sebelumnya, maka solusi yang kami ajukan pada program pengabdian masyarakat ini adalah memberikan penyuluhan danpelatihan terkait probiotik dan peranannya terhadap kesehatan termasuk terhadap sistem imun, diantaranya melalui pembuatan diversifikasi produk probiotik dengan memanfaatkan limbah kulit nanas (tepache)

\section{METODE PELAKSANAAN}

Metode pelaksanaan pengabdian masyarakat yang akan dilakukan pada bulan Mei-Oktober 2020 di PKKRT.6/RW.3 Rungkut Barata. Kelurahan Rungkut Menanggal, Kecamatan Gunung Anyar Surabaya adalah dengan memberikan penyuluhan dan pelatihan. Penyuluhan diberikan dengan cara memberikan materi terkait probiotik seperti pengertian, peranan terhadap kesehatan dan contoh produk pangan yang termasuk probiotik. Kegiatan selanjutnya yaitu praktek/pelatihan membuat produk probiotik dari kulit nanas (tepache). Pada tahapan ini, mitra sebelumnya akan diberikan catatan resep pembuatan tepache, sehingga dapat digunakan sebagai panduan untuk pembuatan produk.

\section{HASIL DAN PEMBAHASAN}

Agenda yang telah dilakukan pada kegiatan ini adalah survei dan persiapan; koordinasi lanjutan dengan calon mitra; dan penyuluhan serta pelatihan. Survei dan persiapan dilakukan untuk 
mengetahui dan mendapatkan gambaran terkait kondisi sekitar calon mitra. Hasil kegiatan pertama ini didapatkan gambaran terkait lokasi calon mitra bahwa daerah sekitar calon mitra terletak di dekat pasar dan toserba, sehingga dirasa mudah untuk mendapatkan bahan baku. Selain itu, lokasi calon mitra juga dikelilingi oleh beberapa penjual nanas dan penjual buah potong, yang mana kulit nanasnya belum termanfaatkan secara optimal dan jumlahnya melimpah. Kegiatan berikutnya adalah koordinasi lanjutan dengan calon mitra yang diwakili oleh oleh RT, dan hasil yang didapatkan adalah waktu pelaksanaan kegiatan.

Kegiatan lanjutan adalah berupa penyuluhan dan pelatihan. Peyuluhan dan pelatihan diberikan dengan cara menjelaskan materi terkait produk yaitu tentang probiotik, yang kemudian dilanjutkan dengan pelatihan pembuatan tepache. Setelah kegiatan pelatihan dan penyuluhan selesai, dilanjutkan dengan pemberian trial kits secara simbolis. Antusiasme warga selama kegiatan berlangsung sangat bagus, hal ini dilihat dari keaktifan warga untuk bertanya pada saat kegiatan. Antusiasme juga dapat terlihat dari warga yang langsung mempraktekkan ilmu yang didapat. Hasil evaluasi kegiatan ini diantaranya dilihat dari hasil praktek mitra dalam mengaplikasikan limbah kulit nanas sebagai tepache. Selain diproduksi dan dikonsumsi untuk pribadi/ keluarga, beberapa warga juga memproduksi tepache dan menjualnya di lingkungan perumahan. Untuk itu, pemanfaatan buah nanas terutama limbahnya (kulit nanas) dirasa mengalami peningkatan, yaitu selain dapat digunakan untuk konsumsi pribadi, juga dapat diproduksi untuk tujuan komersial. Tepache juga dipilih dan diajukan warga untuk lomba Surabaya Smart City 2020, dan mampu masuk dalam peringkat 150 besar. Adapun dokumentasi kegiatan pengabdian ini dapat dilihat pada Gambar $1,2,3,4$ dan 5 .

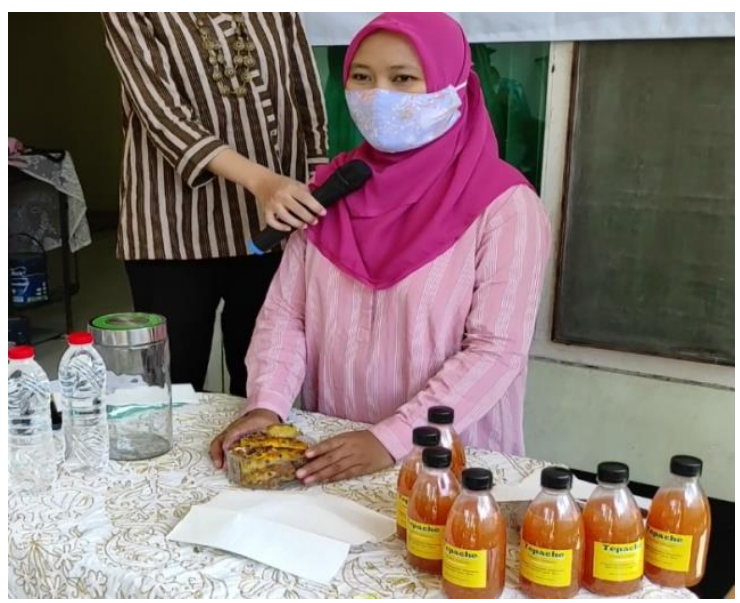

Gambar 1. Penjelasan materi

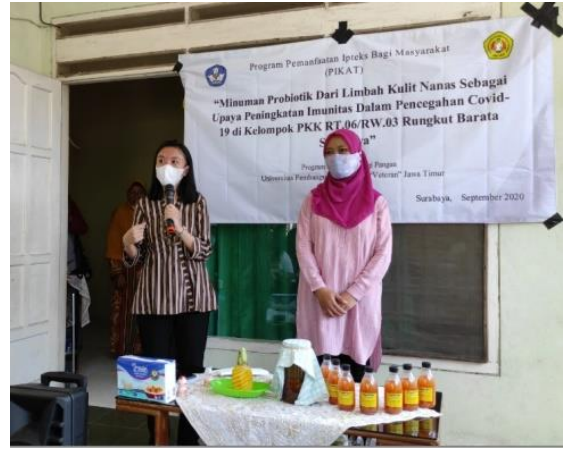

Gambar 2. Pelatihan pembuatan tepache

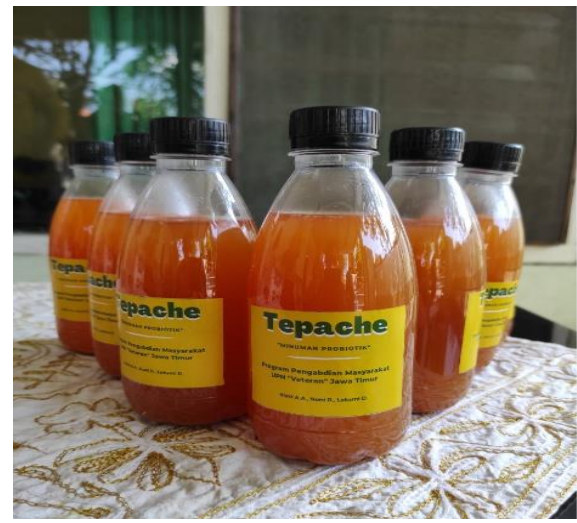

Gambar 3. Hasil produk(tepache)

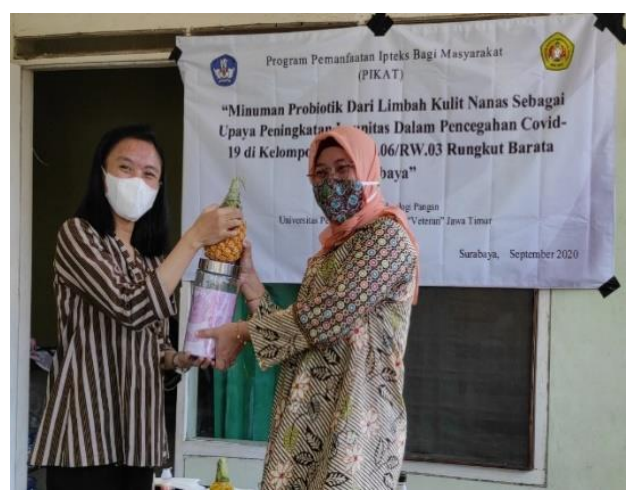

Gambar 4. Penyerahan trial kits secara simbolis

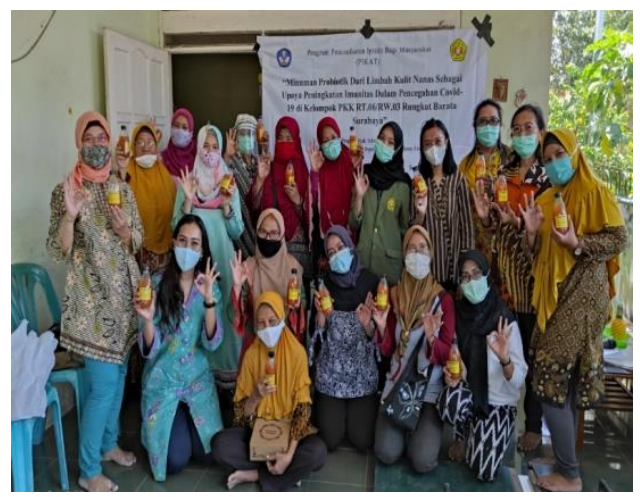

Gambar 5. Dokumentasi dengan mitra 


\section{KESIMPULAN}

Kegiatan pengabdian masyarakat ini berjalan dengan lancar dan mampu memberikan pengetahuan terkait probiotik seperti tepache, khususnya dengan memanfaatkan limbah yang ada. Limbah kulit nanas potensial dimanfaatkan untuk produk pangan fermentasi. Selain dapat memanfaatkan limbah yang ada, tepache dapat digunakan sebagai salah satu alternatif probiotik. Tepache dianggap potensial untuk dikembangkan menjadi produk komersial terlebih di masa pendemi.

\section{UCAPAN TERIMAKASIH}

Penulis mengucapkan terimakasih kepada LPPM (Lembaga Penelitian dan Pengabdian Kepada Masyarakat)Universitas Pembangunan Nasional "Veteran" Jawa Timur melalui SKIM PIKAT (Pemanfaatan Ipteks Bagi Masyarakat) dengan nomor kontrak SPP /37/ UN.63.8/ DIMAS /VII/ 2020 atas bantuan pendanaan dalam kegiatan ini.

\section{DAFTAR PUSTAKA}

[1] WHO. 2020. Coronavirus Disease (Covid-19) Pandemic. https://www.who.int/. Diakses tanggal 31 Mei 2020.

[2] Satgas Penanganan Covid-19. 2020. Gugus Tugas Percepatan Penanganan Covid-19. https://covid19.go.id/. Diakses tanggal $31 \mathrm{Mei}$ 2020.
[3] Pemerintah Provinsi Jatim. 2020. Jatim Tanggap Covid-19. http://infocovid19. jatimprov.go.id/. Diakses tanggal 31 Mei 2020.

[4] Wijayana, S., A. Kumalaningsih, U. Setyowati, Efendi, dan N. Hidayat . 1991. Optimalisasi Penambahan Tepung Kulit Nanas dan Proses Fermentasi pada Pakan Ternak terhadap Peningkatan Kualitas Nutrisi. ARMP (Deptan). Universitas Brawijaya. Malang. Hal 208

[5] O'Hara, A., Shanahan, F., 2007. Mechanisms of action of probiotics in intestinal diseases. Sci. World J. 7, 31-46.

[6] Bermudez-Brito, M., Plaza-Díaz, J., MuñozQuezada, S., Gómez-Llorente, C., Gil, A., 2012. Probiotic mechanisms of action. Ann. Nutr. Metab. 61 (2), 160-174.

[7] Hill, C., Guarner, F., Reid, G., Gibson, G.R., Merenstein, D.J., Pot, B., Morelli, L., Canani, R.B., Flint, H.J., Salminen, S., Calder, P.C., Sanders, M.E., 2014. Expert consensus document. The International Scientific Association for probiotics and prebiotics consensus statement on the scope and appropriate use of the term probiotic. Nat. Rev. Gastroenterol. Hepatol. 11, 506-514. 